FIU Law Review

Fall 2007

\title{
What's the Fuss? Constitutionalism, Internationalism, and Original Method
}

Francisco Valdes

University of Miami School Law

Follow this and additional works at: https://ecollections.law.fiu.edu/lawreview

Part of the Other Law Commons

Online ISSN: 2643-7759

\section{Recommended Citation}

Francisco Valdes, What's the Fuss? Constitutionalism, Internationalism, and Original Method, 3 FIU L. Rev. 1 (2007).

DOI: https://dx.doi.org/10.25148/lawrev.3.1.5

This Symposium is brought to you for free and open access by eCollections. It has been accepted for inclusion in FIU Law Review by an authorized editor of eCollections. For more information, please contact lisdavis@fiu.edu. 


\title{
FIU LAW REVIEW
}

\begin{tabular}{lrr}
\hline Volume 3 & Fall 2007 & Number 1 \\
\hline ○ 2007 by Florida International University &
\end{tabular}

\section{SYMPOSIUM}

Florida International University

College of Law Inauguration

The Intersection of United States Constitutional Law with International and Foreign Law

What's the Fuss?

\section{Constitutionalism, Internationalism, and Original Method}

\author{
Francisco Valdes
}

\section{INTRODUCTION}

In recent years, the role of internationalism in the interpretation of the Constitution of the United States has flared up, yet again. This time, the discussion takes place within a larger jurisprudential maelstrom: the assertion of "originalism" as a viable—if not the only legitimate-approach to constitutional interpretation. While originalists

* Professor of Law, University of Miami School of Law. Co-Director, Center for Hispanic \& Caribbean Legal Studies. I thank the Dean and faculty for inviting my participation in this event and symposium. I am especially grateful to participate because of the occasion they mark: the inauguration of the facilities for the Florida International University College of Law. Because I arrived in Miami from Cuba when I was a mere five years of age, I consider this effectively my "hometown." Therefore, I am delighted to witness this day, when a public law school (finally) becomes a reality in this community. With the substantive note struck by this inauguration and symposium, I hope and trust that internationalism will flourish here for many years to come. All errors below are mine. 
have painted differing portraits of their view(s), a common and bedrock tenet is that the federal Constitution must be viewed through the Framers' subjective prism: in other words, what the original Framers "intended"-or what the sitting judges think "they" intended. Taking originalism seriously thus invites, or compels, that we consider the Framers' original methods, or approaches, to constitutionalism itselfto the process of forging constitutional meanings, including the role and relevance of comparative and international analysis, or internationalism.

A review of the known historical record quickly shows the original generation embracing internationalism as constitutional method. Though the notion of a stable, unitary, collective "intent" among the framers of the Constitution on any given detail is conceptually incoherent, key figures among those at the Constitutional Convention routinely and deliberately turned to other societies' experiences for insight and guidance. Time and again the Framers and their contemporaries drew comparative lessons intentionally for "domestic" application. $^{3}$ If we take originalism seriously, intellectual honesty requires us to take internationalism seriously.

It thus seems ironic-perhaps Orwellian-that adherents of originalism would be among the most strident enemies of internationalism as constitutional method. ${ }^{4}$ This discontinuity suggests a substantive incoherence in the elaboration of originalism as a serious approach to constitutional interpretation. This discontinuity further suggests an unprincipled application of originalism's basic tenets to attempt justification of an anti-internationalist stance. But to what end? If strategic, this discontinuity raises doubts not only about the conceptual viability of originalism in the longer term, but also about the rule of law in the United States under the rule of self-styled "originalist" judges.

\footnotetext{
1 See infra notes 40-53 and accompanying text (on "intent" in constitutional interpretation).

2 In this brief Essay I sometimes refer to "internationalism" as shorthand for the varied kinds of materials and uses that could be imagined in a discussion of this symposium's topic. Of course, the specific materials or uses can help determine doctrinal or detailed analysis of a particular substantive issue, but the focus of this Essay is not on technical analysis. Instead, this Essay attempts to situate the current sense of controversy regarding this topic against the broader sociolegal and sociopolitical background of this historical moment, and to do so in a way that validates and celebrates the internationalist mission of this institution. See infra notes 44-72 and accompanying text (amplifying these points).

3 See infra notes 19-25 and accompanying text (on internationalism in original and early practices).

4 See infra notes 34-51 and 66-72 and accompanying text (on relationship between originalism and anti-internationalism today).
} 
Because the federal judiciary generally, and the U.S. Supreme Court specifically, are under the influence of judges who profess allegiance to originalism, the questions and doubts raised by this discontinuity are of enormous import to anyone interested in the preservation of constitutional governance in the United States. And as this symposium illustrates, the role of internationalism in U.S. legal culture remains alive. Indeed, internationalism in and through legal culture is central to the legislative mandate for this university as a whole. With

5 As elaborated below, the past several decades have witnessed a sweeping recomposition of the federal judiciary along increasingly politicized lines. See infra notes 53-65 and sources cited therein (on the jurisprudential politics of the culture wars). See generally RICHARD Hodder-Williams, THE Politics of the U.S. Supreme COURT 33-45 (1980) (on the politics of the Nixon nominations to the Supreme Court). For other accounts covering recent decades, see David M. O'Brien, Storm Center: The Supreme COURT In AMERICAN Politics 56-86 (2000); Richard L. PACElle, JR. The Transformation of THE Supreme CourT's Agenda: From the New Deal to the Reagan Administration (1991); Martin H. Redish, The Federal Courts in the Political Order (1991); Herman Schwartz, Packing the Courts: The Conservative CAMPAign to Rewrite the Constitution (1988); Francisco Valdes, Culture, "Kulturkampf" and Beyond: The Antidiscrimination Principle Under the Jurisprudence of Backlash, in THE BLACKWELL COMPANION TO LAW AND SOCIETY 271, 287-91 (Austin Sarat ed., 2004), (providing an extensive bibliography on the general topic).

This intensification of politics in judicial appointments became most noticeable during the Reagan administrations. See Sheldon Goldman, Reagan's Judicial Appointments at Mid-Term: Shaping the Bench in His Own Image, 66 JudICATURE 335 (1983); Jon Gottschall, Reagan's Appointments to the U.S. Courts of Appeals: The Continuation of a Judicial Revolution, 70 JUdiCATURE 48 (1986-87); Sheldon Goldman, Reagan's Judicial Legacy: Completing the Puzzle and Summing Up, 72 JudiCATURE 318 (1986) (all on President Reagan's judicial appointments and their ideological effects on the federal judiciary). By the turn of the century, President Reagan's escalated ideological scrutiny and techniques to ensure ideological purity had produced a paralyzing polarization in the confirmation process, especially in election years: in 1988, when Ronald Reagan faced a Democratic Senate, the senators approved 42 of his judicial nominees; in 1992, when George Bush similarly faced a Democratic Senate, the senators approved 66 of his judicial nominees; in 1996, when Bill Clinton faced a Republican Senate, the senators approved a mere 17 of his judicial nominees. See Frank Davies, Senate Stalling New Judges: Republicans Block New Judgeships, MiA. HERALD, Feb. 6, 2000, at 1A (reporting the increased blocking of federal judicial appointments on ideological grounds).

However, the same rhetoric and campaign continues to this day, as the daily news reports demonstrate. E.g., Elizabeth Bumiller, Bush Vows to Seek Conservative Judges, N.Y. TIMES, March 29, 2002, at A24; Robert A. Carp, Kenneth L. Manning \& Ronald Stidham, The DecisionMaking Behavior of George W. Bush's Judicial Appointees: Far-Right, Conservative or Moderate? 88 JUDICATURE 20 (2004) (reporting that overall voting patterns indicate that the most recent appointees "are among the most conservative on record").

6 Among the three goals for the establishment of Florida International University was "greater international understanding." In particular, the intent behind this goal was, "to become a major international education center with a primary emphasis on creating greater mutual understanding among the Americas and throughout the world." See, THE STATE UNIVERSITY SYSTEM OF FLORIDA, THE BIRTH OF A UNIVERSITY: FLORIDA INTERNATIONAL UNIVERSITY AND PlAns FOR ITS DEVElopment, 13 (1972). To carry out this goal, the university was charged with development of "special programs and capabilities to serve the citizens and governments of the Americas and of the world." Id at 16. To accomplish this goal, the university was also charged with cultivating a faculty, student body, and other resources to "optimize" this mandate. Id at 17. On a different but related point the Florida Legislature chartered the Col- 
these general and specific circumstances in mind, this Essay explores these themes to help clarify not only the current fuss over the proper role of internationalism in constitutional interpretation, but also to help clarify the larger jurisprudential backdrop that frames and fuels it. As we shall see, this inquiry leads to the three-way intersection of strategic legal isolationism, "originalism" and the culture wars.

To begin with, consider this:

Powerful and ingenious minds, taking, as postulates, that the powers expressly granted to the government of the Union, are to be contracted by construction, into the narrowest possible compass, and that the original powers of the States are retained, if any possible construction will retain them, may, by a course of well digested, but refined and metaphysical reasoning, founded on these premises, explain away the constitution of our country, and leave it, a magnificent structure, indeed, to look at, but totally unfit for use. They may so entangle and perplex the understanding, as to obscure principles, which were before thought quite plain, and induce doubts where, if the mind were to pursue its own course, none would be perceived.

John Marshall wrote these compelling words during the nation's infancy. What is the prescription in such a case? According to Chief Justice Marshall, writing in 1824 for the Court: "In such a case, it is peculiarly necessary to recur to safe and fundamental principles to sustain those principles, and when sustained, to make them the tests of the arguments to be examined.",

I propose that we do that today: I propose that we heed that original advice, and follow original method, as we consider the topic of this symposium.

To do so, this Essay endeavors to bring into focus a triangular linkage that helps explain what today's anti-internationalist fuss is all about. The first linkage is the connection between "originalism" and the role of international or foreign materials in the interpretation of the federal Constitution.' The second linkage is the relationship between originalism and the sociolegal struggles of the present time and

lege of Law of this university, whose facilities we inaugurate today with this symposium, in order to promote the access of social minorities to legal education and law practice. See, FL ST $\S$ 240.7101 (2000).

7 Gibbons v. Ogden, 22 U.S. (9 Wheat.) 1, 222 (1824) (striking down inter-state ferry licensing laws in conflict with federal commerce powers).

$8 \quad$ Id.

9 See infra notes 34-43 and accompanying text (on this interconnection). 
the past half century or so, which in recent years have increasingly become known as the "culture wars" of North America. ${ }^{10}$ The third linkage brings the inquiry back full circle, to the interconnections between the specific fuss over internationalism and the more general noise created by cultural warfare. ${ }^{11}$ The pivot point in this three-way linkage thus appears to be originalism itself. Yet, originalism is itself also a product of the same forces and dynamics that help to set up the larger dynamics of cultural warfare. Therefore, though originalism appears as the pivot point in this analysis, we must always keep in mind that the cross-relationships binding originalism to the other two points of this triangular linkage are dialectical, fluid and mutually reinforcing: not only does originalism help to beget the problems and controversies addressed below, but they, in turn, help to animate and organize the jurisprudential backlash that has formed, most recently under the rubric of originalism, since the late 1930s and up to this very moment.

The first step in this effort, in Part I below, is to acknowledge the history of uses of international or foreign materials in the interpretation of the Constitution, from before the founding to the present. With this historical context in place, the second step, in Part II, is to situate the current fuss in its contemporary jurisprudential context. Only after this effort can we begin to consider seriously, in Part III, the legitimate questions that this topic entails. Along the way, this analysis shows that internationalism as constitutional method is not only permissible, but also fully compatible with original method-method that effectively amounted to comparative and critical theorizing about the design and operation of constitutionalism in a heterogeneous, commercial and representative democracy.

\section{I. "FOREIGN AND INTERNATIONAL MATERIALS": HISTORY AND BEYOND}

Substantively and conceptually, this topic raises at least four sets of definitional questions. The first of these focuses on the nature of the materials themselves; that is, the kinds of "foreign and international" materials under discussion. These materials can be defined broadly or narrowly, including foreign court and international court decisions interpreting domestic or international law, such as terms of treaties and similar agreements, or of customary international law, and

10 See infra notes 50-66 and accompanying text (on this linkage).

11 See infra notes 66-72 and accompanying text (on this relationship).

12 See infra notes 52-55 and accompanying text (on New Deal showdown between the President and the judges). 
the like..$^{13}$ The second set of questions involves time, or timing-when in time are these materials, however defined, being used? These questions focus on the distinction, if any, between framing and interpreting a Constitution. ${ }^{14}$ The third set of questions focuses on the uses or applications of these materials. These questions focus on whether the materials are used in a primary way, where they serve as the principal basis or rationale for the determination of a point of law, or in a secondary way, in which they are used to supplement the rationale for a determination or conclusion..$^{15}$ And finally, the fourth category of questions focuses on who is using these materials, however defined, and at whichever point in time. Thus, this fourth category of questions focuses on who the legal actor is, in a structural or institutional sense-a Framer, a judge, or an elected official? ${ }^{16}$ The answers to these questions can help to establish parameters for a doctrinal or technical analysis, but the underlying point is that the original practices of the Framers and their generation in fact scrambled across the various categories suggested by any given answer to these (and similar) questions.

Since then, full-fledged articles have been, and will be, written on the various ways in which these kinds of questions may be re-framed and re-answered. ${ }^{18}$ This brief Essay is not devoted to a review of these extensive materials, nor to a microscopic dissection of any portion of

13 See, e.g., Osmar J. Benvenuto, Note, Reevaluating the Debate Surrounding the Supreme Court's Use of Foreign Precedent, 74 FORDHAM L. REV. 2695, 2700-03 (2006) (reviewing the subcategories of materials and uses).

14 See infra note 33 (on the distinction).

15 See infra notes 19-33 and accompanying text (on traditional uses of these kinds of sources or analysis).

16 The focus in this Essay is on the Framers during the founding, and on judges since, due to their written record in the form of published opinions. See infra notes 17-33 and accompanying text (on judicial uses since the Founding).

17 In other words, the practices of the original generation cannot be tidily contained within any given category. See infra notes 19-26 and accompanying text (on the history of internationalist and comparativist practices since the founding).

18 The various articles cited throughout this Essay provide one good sampler. For other informative examples, see generally Bruce Ackerman, The Rise of World Constitutionalism, 83 VA. L. REV. 771 (1997); Roger P. Alford, In Search of a Theory for Constitutional Comparativism, 52 UCLA L. REV. 639 (2004-2005); Roger P. Alford, Misusing International Sources to Interpret the Constitution, 9 AM. J. OF INT'L L. 57 (2004); Donald E. Childress III, Note, Using Comparative Constitutional Law to Resolve Domestic Federal Questions, 53 DukE L. J. 193 (2003-2004); Sujit Choudhry, Globalization in Search of Justification: Toward a Theory of Comparative Constitutional Interpretation, 74 IND. L. J. 819 (19981999); Samuel C. Kaplan, "Grab Bag of Principles” or Principled Grab Bag?: The Constitutionalization of Common Law, 49 S. CAL. L. REV. 463 (1997-1998); Christopher McCrudden, A Common Law of Human Rights?: Transnational Judicial Conversations on Constitutional Rights, 20 OXFord J. LegAl STUD. 499 (2000); Peter J. Spiro, Treaties, International Law, and Constitutional Rights, 55 Stan. L. Rev. 1999 (2002-2003); David A. Strauss, Common Law Constitutional Interpretation, 63 U. CHI. L. REV. 877 (1996). 
them. Instead, this Essay aims to use and celebrate those materials, and the insights they provide, as a point of departure for consideration of the focus that this symposium invites: what is the proper role of internationalism in the legal culture of this nation, and why? As we approach this topic and the current fuss over it, we might do well to begin at the beginning of this story.

Historically, the Framers set a fairly straightforward example, employing comparative study repeatedly before their framing of the Constitution, during their actual composition of the Constitution, and after the completion of the framing, while in the process of ratification. ${ }^{19}$ The founding generation more broadly did likewise: that is, not only the Framers in Philadelphia in 1787, not only those privileged actors able to participate in the post-Philadelphia state ratifying conventions, but also the people who lived at that time, and in particular, the judges of that original generation, who originally interpreted the handiwork of their contemporaries, and who left a relatively clear record in the form of their published opinions. ${ }^{20}$ The founding generation, including the Framers, turned to comparative study to try to give meaning to constitutionalism, writ large, in the United States after, as well as before, having framed that document.

Moreover, since that original generation, successive generations of judges of all political stripes, appointed by politicians of all political persuasions, have done the same. ${ }^{21}$ They have done so, in the early parts of the Republic, up until around the Civil War, while focusing on the rights of the sovereign, the "law of nations"- what "civilized" nations thought were the "rights" of sovereigns. Since the Civil War, and up until around the New Deal, and thereafter, especially after World War II, the focus has shifted: the focus of comparativism in United States constitutionalism, since the mid-twentieth century, has shifted from elaborating the powers of sovereigns under the Constitution to elaborating the rights of the sovereigns' subjects under the same document. That is, a focus toward civil and human rights that limit the power of sovereigns. In both of these periods-whether focusing on sovereigns or subjects-comparative judicial methodologies have al-

19 One telling example is the Federalist Papers, which used comparativist and internationalist argumentation to explain the substantive contents of the Constitution to urge its ratification. E.g., David Fontana, Refined Comparativism in Constitutional Law, 49 UCLA L. REV. 539, 580 n. 194 (2001-2002) (providing examples).

20 The various illustrative cases discussed in this Essay provide some examples. For additional ones, see infra note 22 and sources cited therein (on the uses of these materials over history).

21 For an extensive review, see Fontana, supra note 19, at 574-90 (tracing comparativist practices from the founding to the present, by framers, judges, and other public figures). 
ways been part and parcel of constitutional practice in the United States.

In the early years of the country, before the Civil War, this long and varied history is exemplified by the multiple pronouncements of the individual justices in the 1857 case of Dred Scott. ${ }^{23}$ In that case, the judges upheld the institution of slavery and invalidated a congressional statute prohibiting it in certain areas of the United States. To arrive at that result, the judges, as is often times the case, relied on many standard sources of constitutional meaning, including text, intent, and doctrine. Among those sources were repeated references to international and comparative materials, oftentimes phrased in terms of "civilization" or God or nature. ${ }^{24}$ These references, moreover, were not limited to the judges in the majority. On the contrary, the dissenting judges also relied on foreign and international materials, in similar ways, to arrive at the diametrically opposite conclusion in that case. Indeed, a careful examination of the voluminous writings of the judges in that case can serve as a mini-case study in the varied uses of international and foreign materials in the interpretation of the United States Constitution. And, as these multiple opinions vividly illustrate these uses can produce strikingly opposing results.

Within two decades, the Supreme Court again made law while using comparativist and internationalist analysis in the case of Bradwell v. State of Illinois. ${ }^{26}$ In that 1872 case, the judges concluded that states like Illinois could enact statutes prohibiting women like Bradwell from the practice of law, in part because "female attorneys at law were unknown in England" and because "God designed the sexes to occupy different spheres of action ... it belonged to men to make, apply, and execute the laws." ${ }^{27}$ These kinds of globalized, grandiose references to custom, history, tradition, religion and God illustrate how transnational or international frameworks were routinely used by federal judges at the highest levels as a form of juridical comparativism to help justi-

22 E.g., Fontana, supra note 19. For other excellent reviews of historical practices since the founding, see Gerald L. Neuman, The Uses of International Law in Constitutional Interpretation, 98 AM. J. OF INT'L L. 82 (2004); David M. O’Brien, More Smoke than Fire: The Rehnquist Courts use of Comparative Judicial Opinions and Law in the Construction of Constitutional Rights, $22 \mathrm{~J}$. L. \& POL. 83 (2006).

23 Dred Scott v. Sandford, 60 U.S. 393, 477-86 (1857).

24 For an insightful review, see Mark W. Janis, Dred Scott and International Law, 43 COLUM. J. TRANSNAT'L L. 763 (2004-2005).

25 Id. at 782-808 (elaborating a detailed review of international or comparative analysis in each of the opinions in that case, including their varied, even contradictory, conclusions).

2683 U.S. 130 (1872).

27 Id. at 132, quoting and affirming Supreme Court of Illinois. 
fy rulings interpreting the Constitution and "domestic" state or federal laws.

In modern times, another notorious ruling illustrates the same basic points. In the 1986 case of Bowers v. Hardwick, ${ }^{28}$ the judges of the Supreme Court upheld a state statute outlawing all sexual relations other than traditional intercourse, as applied to a same-sex couple. Again, to arrive at that result, the judges appealed to various kinds of sources to interpret and apply the Constitution, including precedent, history and intent. Again, among those, were globalized appeals to comparative and international sources. ${ }^{29}$ Thus, in this case we see a continuation of the practices exemplified in Dred Scott and Bradwell.

Most recently, in the 2003 case of Lawrence v. Texas, ${ }^{30}$ the Supreme Court reversed its ruling in Bowers v. Hardwick, once again replicating the same basic scenario. In Lawrence, the judges invalidated a state statute specifically focused on prohibiting same-sex sodomy. To do so, the judges again relied on multiple sources of interpretation. Once again, among those sources we find international and foreign materials. ${ }^{31}$ Thus, each of these four well-known cases, spanning most of the nation's history, help to bring into focus some basic patterns regarding the uses of international and foreign materials in U.S. constitutional cases.

This quartet of cases show that judges appointed during different times by different politicians have relied on international or comparative analysis at least from time to time, and with little or no fanfare. Apparently, none of them subscribed to an absolute or categorical exclusion of comparativst analysis in constitutional interpretation and adjudication. In addition, we see in this quartet how different judges tend to commonly employ international or foreign materials in a secondary manner; that is, in a manner that reinforces or supplements a determination or conclusion already driven principally by other sources of interpretation. ${ }^{32}$ Usually, then, international and comparative analysis serves to confirm or corroborate a conclusion that is suggested or demanded by other sources considered more controlling.

Finally, this high-profile quartet illustrates how the same methodology_international or comparative analysis_can be deployed to

28478 U.S. 186 (1986).

29 Id. at 196 (Burger, C.J., concurring) (citing to Christian history, traditions and civilization, chiefly in European countries, to help interpret Fourteenth Amendment).

$30 \quad 539$ U.S. 558 (2003).

31 Id. at 574-78 (reviewing international, and other, sociolegal developments to help interpret the Fourteenth Amendment).

32 In each case, the judges cited to positive texts, precedents and doctrine, as well as intent or purpose, and other standard sources of interpretation in adjudication. See supra notes 23-31 and sources cited (on these cases). 
achieve diametrically opposed results when measured in ideological or political terms. These cases thus show that internationalist or comparativist approaches to interpretation serve no fixed ideological master; the method is available to judicial appointees of different political persuasions, and can be used willfully as tools to help accomplish preferred results. At a minimum, the multiple opinions in these cases display that employment of international or comparative sources in constitutional interpretation is neither new nor novel, regardless of political or jurisprudential affiliations.

In sum, it is fair to say that international and foreign materials, whether broadly or narrowly defined, have seen their use in United States Supreme Court's and other courts' decisions in many permutations. As we have seen in cases such as Dred Scott, Bowers, and Lawrence, Supreme Court justices throughout the nation's history have invoked "foreign and international" sources-whether defined broadly or narrowly - to create the boundaries of individual rights, as well as the powers of sovereign, in the name of the Law, and specifically of the Constitution. In doing so, these Supreme Court justices have followed the examples set by the Framers specifically, and by the founding generation more broadly. Those original examples show that "foreign and international materials"-defined both narrowly and broadly-were incorporated in extremely conscious ways into the substance and design of the Constitution and later, after its adoption, again in formal interpretive acts. ${ }^{33}$ In some cases, we may find the results agreeable; in other cases, we will find the results disagreeable; in all cases, however, the methodology has been relatively clear: judicial appointees since the founding have repeatedly relied on international and foreign materials in the performance of their formal adjudicative acts under the Constitution of the United States. Thus, in the face of diverse results, we find a record that is both regular and modest: typically, whether in elaborating the rights of the sovereign, or the individual, comparativism in U.S. constitutionalism has served as a backup rationale, sometimes even as a throw-a-way line.

So, one might reasonably ask: "What's the big fuss all about, all of a sudden?"

33 Scalia famously makes a distinction between framing and interpreting a Constitution, but the distinction is made as a conclusory assertion that, to me, is not at all self-evident. See, e.g., Transcript of Discussion Between U.S. Supreme Court Justices Antonin Scalia and Stephen Breyer 23 (Constitutional Relevance of Foreign Court Decisions), AU Washington College of Law, Jan. 13, 2005. Apparently, the distinction also was not self-evident to generations of judges throughout the nation's history, whose practices do not corroborate any such distinction, as illustrated by the landmark cases over the course of the nation's history noted in this Essay. See also supra note 22 and sources cited therein (on historical judicial practices). 


\section{HERE'S THE FUSS: THE POLITICS OF “ORIGINALISM” AS BACKLASH JURISPRUDENCE}

The big and relatively sudden "debate" over internationalism and constitutionalism can be traced proximately to the actions of a particular individual: Antonin Scalia, who reached out four times in eleven months-during 2004 and January 2005-to stir up a fuss over the referencing of foreign and international materials in constitutional analysis. One high-profile occasion was his 2004 keynote at the Annual Meeting of the American Society of International Law. In addition, during 2004 he used his dissent in Olympic Airways v. Husain, and then his concurrence in Sosa v. Alvarez-McChain, to inscribe his sentiments onto the nation's formal legal heritage. ${ }^{34}$ Another was his celebrated 2005 exchange with Justice Breyer at American University's Washington College of Law. In each instance he decried the influence of foreign and international materials in domestic legal culture and espoused a legal neo-isolationism in the name of "originalism" as method.

Yet Justice Scalia is more than just a tad inconsistent on the particular point he has chosen to pick here: for example, a 2006 study of all Supreme Court opinions, before Justices O'Connor and Rehnquist departed, shows empirically that, in recent and current times, all of the justices repeatedly reference international materials in their opinions, including Justice Scalia. ${ }^{36}$ In fact, Justice Scalia is in the top three, tied with former Chief Justice Rehnquist and right behind Justices Kennedy and Breyer. ${ }^{37}$ This particular inconsistency, as noted further below, is part of a larger pattern or record of strategic adjudication established under the banner of "originalism" during the past two decades or $\mathrm{so.}^{38}$

Despite that freighted detail, this sustained denunciation seemed to swell all of a sudden, and created lots of buzz, precisely because it issued from one of the current appointees to the Supreme Court. This fuss thus illustrates the power of that office to create spectacle, if the

34 See Olympic Airways v. Husain, 540 U.S. 644, 658 (2004) (Scalia, J., joined in pertinent part by O'Connor, J., dissenting); Sosa v. Alvarez-Machain, 542 U.S. 692, 750 (2004) (Scalia, J., concurring in part and concurring in the judgment). For a review of this chronology, see Melissa A. Waters, Justice Scalia on the Use of Foreign Law in Constitutional Interpretation: Unidirectional Monologue or Co-constitutive Dialogue, 12 TUlSA J. COMP. \& INT'L L. 150, 152-56 (20042005) (providing a more detailed substantive account).

35 See supra note 33.

36 O'Brien, supra note 22, at 11 (documenting uses in each justices' opinions).

37 Id. at 12-14 (setting out detailed charts).

38 See infra notes 50-52 and accompanying text (on originalism as "practice"). 
holder has the will and wits for it. More important to this analysis, however, is that in each instance Justice Scalia acted professedly and pointedly in the name of what he describes as originalism, ${ }^{39}$ and therefore the motivations behind that larger jurisprudential campaign must be understood so that we may situate the specific fuss in its contemporary, as well as historical, context.

While many variants of "originalism" percolate in contemporary legal culture, in general, the label refers to the viewpoint that would privilege "Framers' intent" (and related historical indicia) as the first and best answer to all constitutional questions. ${ }^{40}$ As Justice Scalia, the most vocal proponent of this one-step approach, has argued: "Now, my theory of what I do when I try to interpret the American Constitution is I try to understand what it meant, what it was understood to mean when it was adopted. And I don't think it changes since then." ${ }^{41}$ This approach would seem to freeze any "foreign" or "international" materials out of all constitutional equations. Over time, the societal effects of this choice are foreseeable, if not intentional: this choice slowly but surely serves to keep the nation cast in a "traditional" hierarchy drawn from the 1700s. ${ }^{42}$ This exclusively backward-looking choice does not reflect the the Framers' own example, as already noted, nor does it reflect what they intended their posterity to do with their handiwork. On the contrary, in Philadelphia they exchanged promises to keep their deliberations strictly secret and, in addition, they agreed to shut the windows of Independence Hall during all of that hot sum-

39 One example is his interweaving of originalism in the elaboration of his views on internationalism during the January 2005 exchange with Justice Breyer at American University. See supra note 33, at 8-9 (using the Eighth Amendment to illustrate the point).

40 For one notable example, see Antonin Scalia, Originalism: The Lesser Evil, 57 U. CIN L. REV. 849 (1989) (arguing for originalism but allowing for "faint-hearted" originalism). This push toward "originalism" became a formal agenda during the 1980s. See, e.g., Edwin Meese III, Interpreting the Constitution, 13 in INTERPRETING THE CONSTITUTION: THE DEBATE OVER ORIGINAL INTENT (Jack N. Rakove ed. 1990) (promoting originalist arguments as formal policy when Attorney General under Ronald Reagen). Other backlashers have promoted similar arguments during this time, see infra note 47 and sources cited therein, even as well-established approaches to interpretation continue to guide contemporary constitutionalism. See, e.g., Stephen Breyer, Our Democratic Constitution, 77 N.Y.U. L. REV. 245 (2002) (questioning contemporary versions of originalism and their selective application); see also William J. Brennan, Jr., The Constitution of the United Sates: Contemporary Ratification 23, in INTERPRETING THE Constitution: The Debate Over Original InTENT (Jack N. Rakove ed. 1990) (rejecting originalism as espoused in modern times).

41 See supra note 33 , at 8.

42 For more discussion of similar points, see Francisco Valdes, The Constitution of Terror: Big Lies, Backlash Jurisprudence and the Rule of Law in the United States Today, 7 NEV. L.J. 973 (2007) [hereinafter Constitution of Terror]. 
mer-both actions taken for the express purpose of precluding later speculation amounting to this sort of constitutional gaming.

This type of present-day originalism consequently has been named a "one-step" approach to the serious and complex business of constitutional interpretation. ${ }^{44}$ Under this simplistic approach, all that this required is for today's appointees to peer back into the distant past and then re-enact whatever choices they imagine might have transpired in the past. Obviously, this approach looks only backwards in time. It fails, in other words, to account for complexity in the application of texts to accomplish intended goals under ever-changing circumstances. Rather than "interpret" the Constitution "with fidelity" this backward-focused approach trenchantly overlooks the necessary "second step" in the process of interpreting or "translating" a text for practical application over time and circumstance-in much the same way that federal judges of all persuasions have been doing routinely since the time of John Marshall.

Under this one-step approach, the nation's government would not be empowered to establish and maintain an Air Force, simply because the text of the Constitution itself refers only to an Army and Navy, and no other evidence of "intent" is available. Under this onestep version of originalism and its related practices, the powers of the national government methodically become contracted into their narrowest possible compass without regard to historical limitations or contemporary complexities. Through this sort of refined and metaphysical process, the Framers' handiwork and hopes are made into a magnificent structure to look at, but totally unfit for long-term use. Without the second interpretive step so necessary to a workable framework of enduring constitutionalism, today's originalist appointees induce doubt, thereby entangling and perplexing constitutional understandings that destabilize modern democratic policy choices and

43 Id. at 980. See also supra notes 21-33 and accompanying text (on historical practices). As is well known, the Framers took extreme pains to foreclose debates about their intent/s: "the sessions were to be strictly secret" and "sentries [were] planted without and within, for example. Indeed, "So scrupulously was the order of secrecy observed that it was not until many years afterward that anything definite was known of what took place in the Convention." MAX FARRAND, THE FRAMING OF THE CONSTITUTION OF THE UNITED STATES 57-60 (1913). James Madison broke this "seal of secrecy" when he posthumously published his famous minutes from the Philadelphia convention-but the edits he performed first remain uncertain, so we have no way of verifying details that may be crucial for originalist-style efforts.

44 For the full exposition of this concept, see Lawrence Lessig, Fidelity in Translation, 71 TEX. L. REV. 1165 (1992-93).

45 These points must be added to the other difficulties that render modern-style originalism conceptually incoherent, an incoherence already well-explained. E.g., Paul Brest, The Misconceived Quest for Original Understanding, 60 B.U. L. REV. 204 (1980) (outlining some key defects in originalism, including conceptual as well as practical flaws). 
help serve and preserve unjust vestiges from colonial days. Rather than aid in the ongoing challenge of principled adjudication, today's originalist tactics toil to fulfill John Marshall's original prophecy.

Under their own terms, then, prevailing versions of originalism fall short of the claims they boast. Their modern-day conception of "intent" as a legal notion overlooks how "intent" as applied to a collective decision must take into account the intentions of different actors within the collective-in this instance, the Framers. Their simplistic conception also is blind to the ways in which both individuals and collectives typically are motivated by mixed intentions. This originalist misconception renders "intent" conceptually incoherent not only because it ignores the measures of the Framers to prevent this misuse of their debates, but also because it relies on an extreme, and perhaps strategic, over-simplification of an otherwise well-understood concept of the common law.

Nonetheless, one-step or modern-day originalists insist that their approach constrains unprincipled exercises of public power, especially by "liberal" federal judges too keen on "rights."

46 Id. See also supra note 43 (on other difficulties with originalist reliance on "intent" in constitutional contexts). For a more extended discussion, see Valdes, The Constitution of Terror, supra note 42, at 977-85 (critiquing originalism's misuse of "intent"). Nonetheless, we must recognize that juridical references to Framers and their intentions do resonate throughout the nation's history. Yet, the record shows that typical historical uses and today's originalist practices are not the same thing. Though references to "Framers' intent" percolate from the original generation on to today, the big difference between then and now can be boiled down, somewhat roughly, to this: during most of the nation's history, Supreme Court justices and other judicial appointees have made frequent and mostly sloppy references to "Framers' intent" to help reinforce or supplement their rationales for a particular determination of law, as the landmark rulings in cases like McCulloch v. Maryland and Gibbons v. Ogden help to illustrate. See Valdes, The Constitution of Terror, supra note 42, at 977-85 (elaborating similar points).

Interestingly, this historical use is somewhat similar to the historical uses of foreign and international materials: as we saw above, foreign and international materials also are used in secondary or supplemental ways, in support of various outcomes, and with apparent sense of systemic discipline. See supra notes 21-33 and accompanying text (on uses). Similarly, as in $\mathrm{McCul}$ loch and Gibbons, judges throughout the nation's history have invoked the intent of the Framers as a flourish to help solidify conclusions of law. See Valdes, The Constitution of Terror, supra note 42, at 980-84 (discussing these cases and related points). In contrast to that historical invocation or use of Framers' intent, today's originalists seek to establish a political and legal culture wherein anything labeled "Framers' intent" becomes the preferred, if not exclusive, basis for determining a point of law. Under originalist accounts of original practices, the category of "Framers' intent" thereby becomes deified, as well as ossified, in much the same way that the category "foreign and international materials" becomes demonized and suppressed. Surface similarities between historical practices and revisionist originalism regarding internationalism (or "intent") are just that; to understand and grapple with legitimate questions raised by internationalism (or "intent") for American legal actors today, we must search not only deeper but also elsewhere.

47 E.g., Kathleen M. Sullivan, Post-Liberal Judging: The Roles of Categorization and Balancing, 63 U. COLO. L.REV. 293, 293 (1992) (noting that "liberal activist judges" are the frequent targets of self-style originalists, who "promise that their replacements will not be so free- 
cipled decision-making are typical of the virtues that originalists assert in support of their interpretive choices, even as today's appointees continue to act otherwise-like "the most activist Supreme Court in history." originalist distaste for individual constitutional rights, and a seeming willingness to do whatever may be necessary to contract and contain them, which in turn helps to explain not only the activist "anti-antidiscrimination agenda" of originalist appointees today ${ }^{49}$ but also the anti-internationalist fuss that Scalia has helped to stir up in originalism's name, and in pursuit of its political agenda.

As this synopsis indicates, and despite furious conclusory assertions to the contrary, modern originalism is a twentieth century invention tailored to contemporary political struggles over rights and power. Modern-day, or one-step, originalism tries to sanctify a particular conception of "Framers' intent" and to deploy that conception selectively to achieve ideological imperatives. This technique may appear valueless, detached and neutral through the creation of distance between now and then-by attributing what "we" do now to what the Framers "originally" would have done then. This technique shifts the sense of choice away from today's judicial appointees and creates an air of simple, cut-and-dried adjudication. But in fact, this practice of so-called originalism is akin to the ploys played by the Wizard of $\mathrm{Oz}$, hiding behind the curtain while pulling behind-the-scenes levers to create both commotion and control.

Thus, in an incisive 2006 article, Robert Post and Reva Siegel observed that:

The current ascendancy of originalism does not reflect the analytical force of its jurisprudence, but instead depends upon its capacity to fuse aroused citizens, government officials and judges into a dynamic and broad-based political

wheeling"). For early influential works of originalist backlashers, see ROBERT H. BORK, THE TeMpting of AMERICA:The Political SEDUCTION OF THE LAW (1990) and RAOUl Berger, Government By Judiciary (1977); see also Robert H. Bork, Neutral Principles and Some First Amendment Problems, 47 IND. L.J. 1 (1971).

48 Thomas M. Keck, The Most Activist Supreme COURT IN History (2004)); see also Peter J. Smith, Sources of Federalism: An Empirical Analysis of the Court's Quest for Original Meaning, 52 UCLA L. REV. 217, 217 (2004) (stating that "a study of citation patterns in federalism cases since 1970 " found that "judges seeking the original understanding are largely unconstrained in their ability to mold the historical record to serve instrumental goals"); see also infra note 65 and sources cited therein (on judicial manipulation of legal rules to reach preferred results in recent decades).

49 See Jed Rubenfeld, The Anti-Antidiscrimination Agenda, 111 YALE L.J. 1141 (2002)(on this terminology, and the originalist judicial opinions that give rise to it).

50 See, e.g., Robert P. Smith, Jr., Explaining Judicial Lawgivers, 11 FLA. ST. U.L. REV. 153 (1983-1984) (documenting this practice). 
movement. To understand originalism's power at the dawn of the $21^{\text {st }}$ Century is to appreciate the ways in which originalism connects Constitutional law to a living, political culture and provides its proponents a compelling language in which to seek constitutional change through adjudication, as well as politics. Political proponents of originalism speak to and incite groups, in order to solidify their political mandates to reconstitute the Court. What is truly remarkable in assessing the performance of originalist judges (and here they speak specifically of Scalia and Thomas) is that they also engage in this same process of political mobilization. These two justices use their judicial opinions as conscious tools to excite the anger, fears and resentment of conservative constituencies and thus to fan the fires of political mobilization.

In short, this latest fuss about the relevance of foreign and international materials in North American constitutionalism is an expression of the role that today's new, ideologically-saturated form of originalism plays in the legal (and political) culture of the United States at this juncture in the nation's history.

As the preceding synopsis suggests, the context for this specific fuss over internationalism is originalism's broader role or function in the construction of the current social, legal and political moment. This role or function renders originalism a jurisprudential vehicle to help expedite, or at least legitimate and facilitate, a roll-back of social and legal developments since the famous showdown in 1937, when another handful of appointees wielded the power of judicial review as a personal baton. In the New Deal's stead, today's originalists envision a "resurrection" of discredited doctrines and old deals that (we had thought) the generations of the mid-twentieth century had transcended. ${ }^{53}$ This anti-rights, roll-back effort, as we see next, travels under the name of "culture war" or backlash kulturkampf.

51 Robert Post \& Reva Siegel, Originalism as a Political Practice: The Right's Living Constitution, 75 FORDHAM L. REV. 545 (2006).

52 For notable accounts of those times, see WiLliam E. LEUCHTEnBURG, FrankLin D. Roosevelt AND tHE NeW DEAL, 1932-1940 (1963); William E. Leuchtenburg, The Origins of Franklin D. Roosevelt's “Court Packing” Plan, 1966 SUP. CT. REV. 347.

53 The term "resurrection" denotes a return from "exile" - which, under this view, began with the emergence of the New Deal and has continued since then. See Special Symposium Issue: The Constitution in Exile, 51 DUKE L. J. 1 (2001) (presenting a symposium devoted to the topic). 
While the term "kulturkampf" traditionally refers to various periods in different social and political settings, ${ }^{54}$ in the United States at the turn of the millennium the term had come to signify the coordination of national political efforts to retrench Civil Rights and New Deal legacies in both social and legal terms. ${ }^{55}$ These orchestrated efforts span multiple categories of identity and policy, but it is no coincidence that twice in sexual regulation cases, Justice Antonin Scalia-againhas raised a fuss. Both times, he invoked the notion of "kulturkampf" explicitly, and each time to deride the Court's ruling protecting a vulnerable social group from formal legal subordination through raw exercises of majoritarian might. Dissenting from Romer v. Evans, and again from Lawrence $v$. Texas, ${ }^{57}$ he ridiculed the majority's analysis and holding as mere participation in the "culture wars" sweeping the United States during the last quarter of the twentieth century. In doing so, Justice Scalia reminds us - again - of the times in which we live, of the context in which these cases have been litigated and adjudicated, and of the mind-set that prompts him to raise his latest fuss, against internationalism, in the service of the same ends.

The stirrings of today's "culture wars" go back to the 1970s and 1980s when the liberal antidiscrimination initiatives of earlier decades were increasingly contested. ${ }^{58}$ By 1989's Supreme Court term, Justice

54 For example, culture wars and kulturkampf are associated with German politics, both during the Bismarckian struggle to assert secular state authority over Catholic dogma in the form of public policy and during the efforts of the Nazi Party to reform German culture in line with their racist ideology. See generally RICHARD J. EVANS, THE COMING OF THE THIRD REICH 118-53 (2003) (focusing on the culture wars waged in Germany as part of the Nazi rise to power).

55 See Francisco Valdes, Afterword-Beyond Sexual Orientation in Queer Legal Theory: Majoritarianism, Multidimensionality and Responsibility In Social Justice Scholarship-Or, Legal Scholars as Cultural Warriors, 75 DENVER U. L. REV. 1409, 1427, n. 70 (1998) (defining term and describing phenomenon).

56517 U.S. 620, 636 (1996) (Scalia, J., dissenting) (striking down state constitutional amendment prohibiting municipal and local governments to protect sexual minorities under antidiscrimination laws).

57539 U.S. 558, 586 (2003) (Scalia J., dissenting) (striking down state law criminalizing only same-sex versions of identical acts). For a further discussion of Lawrence, see supra notes 30-31 and accompanying text.

58 For example, in 1969 the political strategist behind Richard Nixon's 1968 campaign described a "southern strategy" designed to exploit mainstream fears and majoritarian resent-

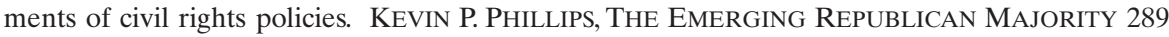
(1969); see also Terrel L. Rhodes, RepublicAns in the SOUth: Voting for the StATE House, Voting FOR THE WHITE House, 19-39 (2000) (arguing that strategy has been successful since then in propelling right-wing Republican politicians into the White House, thus shaping national politics).

The abbreviated account presented below summarizes more detailed analyses on cultural warfare, law and identity, and legal education or consciousness, which I have elaborated elsewhere. See generally Valdes, supra note 5, (focusing broadly on three theoretical perspectivesbacklash jurisprudence, liberal legalisms and critical outsider jurisprudence-to compare their approaches to equality law and policy); Francisco Valdes, Afterword- "We Are Now of the 
Thurgood Marshall was driven to observe publicly that, "the Court's approach to civil rights cases has changed markedly .... It is difficult to characterize last term's decisions as a product of anything other than a retrenching of the civil rights agenda." tion has continued and accelerated. ${ }^{60}$ However, the official declaration of backlash kulturkampf occurred in 1992, from the podium of the Republican National Convention, when presidential contender $\mathrm{Pa}-$ trick Buchanan declared "cultural war" for the "soul of America.," And this declaration of 'cultural war' to justify and direct formally

View”: Backlash Kulturkampf, OutCrit Scholarship and Critical Legal Education, 35 SETON HALL L. REV. 1401 (2005) (summarizing political and doctrinal structure of the culture wars); Francisco Valdes, Afterword-Culture by Law: Backlash as Jurisprudence, 50 VILL. L. REV. 1135 (2005) [hereinafter Culture by Law] (focusing on liberty-privacy constitutional analysis, and the effects of backlash kulturkampf on constitutional privacy doctrine); Francisco Valdes, Warts, Anomalies and All: Four Score of Liberty, Privacy and Equality, 65 OHIO ST. L.J. 1341 (2005) (focusing specifically on Lawrence $v$. Texas and generally on liberty-privacy as a central doctrinal terrain of social and legal retrenchment); Francisco Valdes, Afterword-Beyond Sexual Orientation in Queer Legal Theory: Majoritarianism, Multidimensionality and Responsibility in Social Justice Scholarship-Or, Legal Scholars as Cultural Warriors, 75 DENVER U. L. REV. 1409 (1998) (focusing on the implications of cultural warfare for sexual orientation scholarship specifically, and for all OutCrit scholars generally) [hereinafter Beyond Sexual Orientation]. These works, in turn, inform and are informed by related concerns or issues that form part of my larger scholarly agenda. See Francisco Valdes, Outsider Jurisprudence, Critical Pedagogy and Social Justice Activism: Marking the Stirrings of Critical Legal Education 10 AsIAN L.J. 65 (2003) [hereinafter Critical Legal Education]; Francisco Valdes, Identity Maneuvers in Law and Society: Vignettes of a Euro-American Heteropatriarchy, 71 UMKC L. REV. 377 (2002); Francisco Valdes, Insisting on Critical Theory in Legal Education: Making Do While Making Waves, 12 LA RAZA L. J. 137 (2001); Francisco Valdes, Race, Ethnicity and Hispanismo in Triangular Perspective: The "Essential Latina/o" and LatCrit Theory, 48 UCLA L. REV. 305 (2000); Francisco Valdes, Outsider Scholars, Legal Theory and OutCrit Perspectivity: Postsubordination Vision as Jurisprudential Method, 49 DePaul L. REV. 101 (2000); Francisco Valdes, Afterword-Theorizing "OutCrit" Theories: Coalitional Method and Comparative Jurisprudential Experience-RaceCrits, QueerCrits, LatCrits, 53 U. MiAmi L. REV. 1265 (1999); Francisco Valdes, Queer Margins, Queer Ethics: A Call to Account for Race and Ethnicity in the Law, Theory and Politics of "Sexual Orientation", 48 Hastings L.J. 1193 (1997); Francisco Valdes, Sex and Race in Queer Legal Culture: Ruminations on Identities and Inter-Connectivities, 5 S. CAL. REV. L.\& WOMEN'S STUD. 25 (1995).

59 Hon. Thurgood Marshall, Transcription of Remarks, Annual Judicial Conference, Second Circuit of the United States, 130 F.R.D. 166, 167 (1990).

60 See, e.g., supra note 58 and infra notes $64-65$ and sources cited therein (on backlash through jurisprudence).

61 For contemporary news accounts reporting this remarkable declaration, see Chris Black, Buchanan Beckons Conservatives to Come "Home," Boston GlobE, Aug. 18, 1992, at A12; Paul Galloway, Divided We Stand: Today's “Cultural War” Goes Deeper than Political Slogans, CHI. TRIB., Oct. 28, 1992, at C1. For a more substantive elaboration of cultural warfare in this context, see James Davison Hunter, Culture Wars: The Struggle to Define America (1991); JAmes DaVison Hunter, Before the Shooting Begins: SEARCHING FOR Democracy IN AMERICA'S CULTURE WAR (1994). That formal 1992 declaration was not an idiosyncratic moment, however. Since then, the "angry white male" has emerged as the principal audience and beneficiary of ongoing backlash politicking. See, e.g., Grant Reeher \& Joseph Cammarano, In Search of the Angry White Male: Gender, Race and Issues in the 1994 Elections, in MIDTERM: THE ELECTIONS OF 1994 IN CONTEXT (Philip A. Klinkner ed., 1996)). 
democratic politicking is not unique or isolated. ${ }^{62}$ Although some observers may mistake this ongoing kulturkampf for the typical sort of factional politics envisioned under the Constitution, it is not, as this brief summary suggests. Rather, this backlash kulturkampf is a multifaceted yet methodical pursuit of a roll-back agenda designed to reestablish "old deals" based on the colonial period." As the quotations above indicate, it is a war waged against specifically named minority communities, especially those placed under de jure disabilities during the colonial period, like people of color and women, and others not fairly represented in formal democracy as a result of traditional identity politics.

In constitutional terms, the cumulative patterns of power and politics left in the wake of backlash kulturkampf in recent decades point to a judicial "anti-anti-discrimination agenda." "Under the cloak of

62 E.g., James Kuhnhenn \& Ron Hutcheson, Ashcroft is Next Political Flash Point; Partisan Lines are Clearly Drawn, MIA. HERALD, Jan. 11, 2001 at 1A (reporting on comments after the 2000 presidential selection, making it clear that the naming of a new Attorney General at that time reflected this ongoing backlash pursuit of cultural warfare).

63 As this summary indicates, backlash kulturkampf is waged across three broad fronts or prongs, which are orchestrated to be mutually-reinforcing. The first focuses on electoral politics, including direct referenda, at the local, state and national levels. The second prong or front focuses on federal judicial appointments. The third focuses on targeted uses of the federal spending power. The first prong ensures control of lawmaking power, as well as the power to make judicial appointments. The second then ensures that backlash lawmaking will receive judicial protection, rather than scrutiny. The third enables backlashers to "starve" public programs they despise when the first or second prongs fail to do the job altogether. As a set, this trio of backlash efforts systematically aims to "roll back" the New Deal and Civil Rights legacies of numerous Congresses and Presidents, established democratically during the latter half of the past century. See supra note 58 and sources cited therein (on the substance and structure of backlash kulturkampf).

64 Rubenfeld, supra note 49; see also Keith Aoki, The Scholarship of Reconstruction and the Politics of Backlash, 81 IowA L. REV. 1467 (1996); Kimberlé W. Crenshaw, Race, Reform, and Retrenchment: Transformation and Legitimation in Antidiscrimination Law, 101 HARV. L. REV. 1331 (1988); Kenneth L. Karst, Religion, Sex, and Politics: Cultural Counterrevolution in Constitutional Perspective, 24 U.C. DAVIS L. REV. 677 (1991); Alan D. Freeman, Legitimizing Racial Discrimination Through Antidiscrimination Law: A Critical Review of Supreme Court Doctrine, 62 MINN. L. REV. 1049 (1977-1978); Kenneth L. Karst, Legislative Facts in Constitutional Litigation, 1960 Sup. CT. REV. 75; Stephanie M. Wildman, The Legitimation of Sex Discrimination: A Critical Response to Supreme Court Jurisprudence, 63 OR. L. REV. 265 (1984); cf. Kevin M. Clermont, Theodore Eisenberg \& Stewart J. Schwab, How Employment-Discrimination Plaintiffs Fare in the Federal Courts of Appeals, 7 EMP. RTS. \& EMP. POL'Y J. 547 (2003); Kevin M. Clermont \& Theodore Eisenberg, Plaintiphobia in the Appellate Courts: Civil Rights Really Do Differ from Negotiable Instruments, 2002 U. ILL. L. REV. 947; William B. Gould, IV, The Supreme Court and Employment Discrimination Law in 1989: Judicial Retreat and Congressional Response, 64 TUL. L. REV. 1485 (1990); Charles R. Lawrence, III, “Justice” or "Just Us”: Racism and the Role of Ideology, 35 StAn. L. ReV. 831 (1983); Nancy Levit, The Caseload Conundrum, Constitutional Restraint and the Manipulation of Jurisdiction, 64 NOTRE DAME L. REV. 321 (1989) ; Theodore W. Ruger, Pauline T. Kim, Andrew D. Martin \& Kevin M. Quinn, The Supreme Court Forecasting Project: Legal and Political Science Approaches to Predicting Supreme Court Decisionmaking, 104 
Framers' intent and the like, originalist-identified appointees present their pursuit of this agenda innocuously but falsely as a sort of principled adjudication, in which the chips of social and legal destiny simply fall where they belong. ${ }^{65}$ However, backlash kulturkampf amounts to a kind of "cultural cleansing" that aims incrementally to entrench "original" hierarchies and injustices as "natural" and perhaps perpetual features of the nation's social, cultural, political and economic landscape. From the perspective of backlash originalism, apparently nothing can interfere with this neocolonial ambition-especially "foreign" and international influences beyond the formal control of today's appointees, which might point toward emancipatory meanings when translating constitutional texts.

Thus, backlash kulturkampf not only reflects but also projects a willful agenda of social and legal retrenchment in favor of neocolonial hierarchies. Inevitably, and by design, the civil and other rights of traditionally-subordinated groups are the principal targets of this reactive fury. This agenda, as we see immediately below, seems to drive the timing and content of the originalist anti-internationalist fuss as well.

With this historical, political, and ideological background in mind, the question returns: "So why now?"

Recall that Scalia stirs this particular ruckus up in 2004 and early 2005. What happened in 2003, immediately preceding this sudden tempest? The decision in Lawrence-the ruling from which Scalia bitterly dissented with his second invocation of kulturkampf $!^{67}$ This 2003 case, as noted earlier, reversed Bowers, and cited to social and comparative study in the traditional "by-the-way" method characteristic of the Court throughout history. ${ }^{68}$ This modest and traditional usage of international or foreign sources nonetheless made Scalia go on the offensive with his interventions since then, even though no sim-

Colum. L. REV. 1150 (2004); Smith, supra note 50; C. Keith Wingate, A Special Pleading Rule for Civil Rights Complaints: A Step Forward or a Step Back?,49 Mo. L. REV. 677 (1984).

65 Because traditionally-subordinated social groups are as diverse as American society, backlash kulturkampf affects each "different" outgroup differently. For critical analyses of different groups and situations reflecting backlash kulturkampf, see Nicolas Espiritu, (E)Racing Youth: The Racialized Construction of California's Proposition 21 and the Development of Alternate Contestations, 52 CLEV. ST. L. REV. 189 (2005); Ruben J. Garcia, Comment, Critical Race Theory and Proposition 187: The Racial Politics of Immigration Law, 17 CHICANO-LATINO L. REV. 118, 122 (1995); Kevin R. Johnson, An Essay on Immigration Politics, Popular Democracy, and California's Proposition 187: The Political Relevance and Legal Irrelevance of Race, 70 WASH. L. REV. 629, 650-58 (1995); Kevin R. Johnson, Public Benefits and Immigration: The Intersection of Immigration Status, Ethnicity, Gender and Class, 42 UCLA L. REV. 1509 (1995).

66 Valdes, Culture by Law, supra note 58 (focusing on liberty-privacy rights of sexual minorities).

67 See supra notes 56-57 and accompanying text (on these twin dissents).

68 See supra notes 21-33 and accompanying text (on historical uses). 
ilar furor erupted in 1986 after Bowers had relied on the same or similar sources to justify the opposite result. ${ }^{69}$ Generally, this juxtaposition helps to illustrate how the same methodology-referencing foreign and international materials - can and does cut both ways, ideologically, in judicial interpretations of the United States Constitution. More specifically, the juxtaposition of these two culture war cases, both interpreting the Fourteenth Amendment and the limits it places on states' power to regulate human sexualities, helps to bring into sharp relief how backlash kulturkampf works in constitutional doctrinemaking within the current Supreme Court, and under the guise of modern originalism. ${ }^{70}$

In other words, the juxtaposition of internationalism (and originalist reactions to it) in these two relatively recent cases brings into focus the absurdity - and intellectual dishonesty-of the current fuss. This juxtaposition of uses, results, and reactions in these two relatively recent culture war cases helps to bring the crux of the fuss to center stage: as the 2006 empirical study of internationalism in Supreme Court opinions concludes, "[i]n short, what Justice Scalia adamantly opposes is the Court's use of and reliance on contemporary comparative judicial decisions and international legal developments when construing guarantees for individual constitutionally-protected rights, especially when used to justify the protection, as opposed to the contraction or denial, of those rights." "71 The problem for originalists like Scalia, then, is not internationalism. The problem for them is, instead, individual rights, and, more specifically, the role of law in helping to protect them.

This insight helps to make sense of the apparent inconsistency between originalist complaints and practices regarding internationalism and constitutionalism, and situates the current fuss in the frameworks devised by Rubenfeld, Post \& Siegel, and others. ${ }^{72}$ This resultsoriented insight explains, as well as illustrates, the hidden politics of originalism as an expression of neocolonial ideology, and as a jurisprudential form of backlash kulturkampf. This insight reveals that originalism as practice does not illuminate a principled path to constitutional interpretation. This insight, in sum, helps to bring into sharp relief the three-way linkages between the anti-rights bias of originalism, the culture wars, and the newfound attack on internationalism.

69 See supra notes 28-31 and accompanying text (on the two cases).

70 See supra notes 50-66 and sources cited therein (on the culture wars and originalism).

71 O'Brien, supra note 22 (emphasis supplied).

72 See supra notes 58,64 and 65 and sources cited therein (on backlash and retrenchment). 


\section{BEYOND THE FUSS:TOWARD CONCEPTUAL AND PROCEDURAL DISCIPLINE}

So what now? To serious observers, I suggest that we move beyond the originalist fuss, which serves to distract more than to illuminate. Understanding both the historical and contemporary sociolegal contexts for this fuss, as outlined above, I suggest that we turn to the serious business of answering the legitimate questions of methodology and interpretation raised by international and foreign materials. The challenges are both complex and familiar to those trained in law: international and foreign materials, like all sources of interpretation, are susceptible to manipulation.

Two problems emerge at the outset, and both are well known to legal culture: one is haphazard use, and the other is manipulative use; one is unintentional, and one is intentional. Nothing can bar a willful judge from doing what she wants, as the 1930s taught the nation all too well. ${ }^{73}$ So we can't prevent activism, including today's backlash version, except perhaps marginally by being alert and critically minded. But a possible, principled, curative framework for the systematic use of foreign and international materials in the adjudication of "domestic" disputes can be extrapolated from the history of regularity and modesty that precedes us regarding this topic. Two dimensionsone conceptual, one procedural-must be considered here.

Conceptually, we begin with classic prudential considerations. These familiar considerations counsel that a consistent methodology for the inclusion of international materials, whether narrowly or broadly construed, should be reserved for "hard cases"-for cases where no precedent governs and no predominant answer obtains, or cases presenting novel or complex questions under ambiguous texts or authorities. Easy cases are, well, easy; they fall into decisional categories where a ruling and its basis can be ascertained with relative clarity. But hard cases call for more searching analysis. In hard cases, comparativist and internationalist analyses can illuminate the problem, and better inform the decision-maker's understanding of remedial options.

But prudential considerations also counsel that this more searching inquiry, in these relatively hard cases, should be limited to equivalent contexts - and equivalence in turn has two dimensions to it.

73 See supra note 52 and sources cited therein (on anti-New Deal judicial activism).

74 For the classical exposition of the general themes, see ALEXANDER BICKEL, THE LEAST DANGEROUS BRANCH: THE SUPREME COURT AT THE BAR OF POLITICS 115-16 (1962).

75 For a more substantive elaboration of these points, see Fontana, supra note 19, at 556.

76 Id. at 556-60 (elaborating the concepts of equivalence and context). 
One dimension is general or structural equivalence: this dimension queries whether the comparative analysis employs a legal system and society that can be regarded as analogous to the one in this country. The second dimension is specific or situational equivalence: this dimension queries whether the case under analysis is sufficiently similar to the points of comparison being employed. Thus, specific equivalence focuses on situations, problems, policy issues, the question at hand, whereas general equivalence focuses on systems, cultures and societies. Of course, these two queries are subjective. But they go to the heart of lawyering - of what lawyers actually do for a living, which is to analogize and distinguish. These conceptual points-the focus on hard cases, and on both structural and situational equivalence-thus set the stage for an operational model. The second part, therefore, is procedural-and here the focus is on the role of the litigants, and of trial court judges, in problem-solving through formal adjudication."

Revealingly, Federal Rule of Civil Procedure 44 invites litigants to give notice of their intention to raise issues involving "the law of a foreign country" in a domestic federal case. ${ }^{78}$ In other words, the system itself contemplates and invites the introduction and use of foreign materials by litigants and judges in federal procedures. This Rule was enacted in 1966 and has been amended twice since-1987 was the last time. Having been with us for a while, it requires nothing new or novel to note and operationalize the practices it invites. Similarly, Federal Rule of Civil Procedure 53 instructs and empowers federal trial courts specifically to consider foreign and international materials in the application of rules of law in cases and controversies subject to federal jurisdiction under the Constitution. ${ }^{79}$ This Rule explicitly and unqualifiedly authorizes federal judges to appoint a Special Master in any federal civil case, if the judge finds one is needed to ascertain anything legally relevant to its disposition, including "legal conclusions"anything such as international law, the law of India, the law of England, the law of Brazil, the law of South Africa. Finally, and still in the same jurisprudential and procedural vein, Federal Rule of Evidence 706 empowers federal trial courts to appoint experts to testify regarding complex questions, whether of fact or law, while adjudicating a federal case arising under the laws or Constitution of the United States-facts or laws that may include foreign and international sources or matters. ${ }^{80}$ So the rules both of procedure and evidence,

77 For a more detailed presentation of the procedural points outlined immediately below, see Fontana, supra note 19, at 563-65.

78 FED. R. CIV. P. 44.

79 FED. R. CIV. P. 53.

80 FED. R. EVID. 706. 
enacted specifically for the federal court system, already provide several specific points of substantive entry for foreign and international materials.

Under this arrangement, appellate judges-including those controlling the Supreme Court - then have to deal with these materials in the same way that they have to deal with any other matter or issue preserved by the record in accordance with these and similar rules. And these rules of procedure and evidence have been promulgated formally by the Supreme Court itself. Under this arrangement, at this stage in the nation's history, no need for fussing exists in fact.

Although individual members of the Court may use the power of their offices to create a fuss out of pique, the ensuing tempest should remind us of Chief Justice Marshall's prescient warning. ${ }^{81}$ Rather than obscure basic and familiar knowledge, metaphysical fulminations should prompt us to focus on familiar foundations. In this instance, Scalia's latest fuss should remind us of these ready systemic mechanisms, embedded in the rules of procedure and evidence, for the use of foreign and international materials in federal courts. These mechanisms may not settle the details about the use of any particular material in any particular case or manner. But these mechanisms at least corroborate that the constitutional system of this country is not automatically or structurally hostile to comparativism and internationalism as a method. And they provide practical mechanisms for litigants, attorneys, and judges across the country to continue to do so in good faith, as part of everyday legal practice.

To summarize, then, the analysis outlined here counsels an approach to this topic informed by a sense both of history and of trajectory, a recognition not only of tradition but also of trends-much like the Framers and their generation did with just about everything regarding this Constitution, both before and after its framing. This approach requires a recognition that the practice of internationalism under U.S. constitutionalism is long and venerable, and cuts ideologically both ways over time. Today's noisy "debate" distracts from this history, thus illustrating how today's revisionist originalism operates as a political practice in this particular area, at this particular time. Rather than become entangled in the metaphysical questions that today's originalists set forth, much as Chief Justice Marshall long ago warned us, our challenge is to fashion a principled and workable framework that tackles legitimate substantive issues regarding the uses of foreign and international sources in constitutional interpretation, much as we do when other kinds of questions of law and interpretation, familiar to

\footnotetext{
81 See supra note 7 and accompanying text (quoting Chief Justice Marshall in 1824).
} 
us as legal actors, arise. Thus, the approach urged here calls upon us all to learn from the Framers' original example, as well as from the lessons of history since then, rather than from the politicians in robes who now preach a revisionist history in pursuit of backlash agendas.

\section{CONCLUSION}

History shows a key distinction between what some judges call originalism today, and what the Framers originally did when they were in the shoes that we wear today. The Framers and their contemporaries turned to multiple sources to help them discern socially wise ways of both framing substantive rules of law and then interpreting them in the process of applying them. The Framers and their contemporaries, in their formal institutional capacities, employed this methodology before and after the Constitution; that is, incorporating these materials and this methodology into the original Constitution, as well as extending this incorporation through the continuation of this practice thereafter. Even if we were to look to Framers' intent with respect to internationalism, both in substance and in method, we would find a historical record that illustrates no intent that mandates the strident calls for knee-jerk exclusion that today's fuss features.

In broader context, this sudden fuss over internationalism is a strategic extension of the political and ideological clashes between the New Deal and the "old deals" that had defined North American law and society prior to the cataclysmic events of the mid-twentieth century, including the Great Depression and the Second World War. Those cataclysms, much like the cataclysm of the Civil War the century before, had redefined not only American society, but the view of American society toward its legal order. Thus, both historically and substantively, the background that creates the context for this fuss is the broader political struggle over rights and power under the "rule of law" that commences on these shores in the 1780 s with the debates and activities of the men later called the Framers of this Constitution, and continues to this day in the form of backlash kulturkampf and "originalist" jurisprudence. With these thoughts in mind, we can return to, and conclude with, the momentous occasion at hand: the inauguration of the facilities for this new College of Law, the first public law school in South Florida's history, as part of this international university.

The decision of the Florida Legislature to dedicate this whole university specifically and explicitly to the study of international experience and knowledge in our multicultural society is no mistake, nor aberration, as the calls for legal isolationism issued by today's originalists might seem to suggest. On the contrary, this institution, explicitly devoted to internationalism, helps to illustrate how elected public officials, in different time periods and geographic locations, have dis- 
charged their official duties in a manner that embraces comparative understandings of local or "domestic" issues. The legislative Acts establishing both this university as a whole, and this College of Law specifically, are emblematic of this history, and of the gradual development of a legal culture in this nation under the federal Constitution. Of course, these legislative Acts, and the mandate of this university and college under them, do not rise to a constitutional plane, nor do they illustrate the many types of actual or potential aspects of internationalism and comparativism in U.S. legal culture today. Nonetheless, this institution, and the decision to establish it as such, help both to continue and to illustrate the broader phenomenon of internationalism and comparativism in the domestic legal culture established under the U.S. Constitution. The dedication of this university as a whole to international and comparative studies thus illustrates and continues a long and varied history that stretches even prior to the nation's founding.

It is precisely because original aspirations, commitments, and values are amorphous and subjective that judges have since the founding of the nation returned to comparative analysis in order to distill them for concrete application to particular sets of facts. But, as we have seen, throughout this time various legal actors have deployed comparative practices in diverse settings to accomplish varied results. As we have seen, our predecessors have not always arrived at outcomes that later generations could embrace with a sense of integrity. Indeed, the same types of materials and methodology have been used to repudiate what the very same appeals to international or comparative sources had previously produced, as the juxtaposition of Bowers and Lawrence in recent times so crisply illustrates.

In the end, the task facing each judge-and generation-is to endeavor, in good faith, to employ this methodology in a manner that builds on the aspirations of the Framers, rather then entrenching or exacerbating the political limitations they were unable to transcend in their own day. In the end, as this brief account indicates, the question now (and always) before us regarding the use of international and foreign materials in the interpretation of our laws is not if, but rather how. And the challenge raised by this question, both historically and now, is whether each generation can do so in a manner that helps to build and reinforce aspirational, even if imperfect, commitments to foundational values in favor of liberty and equality. Recent generations have already crafted some basic rules of procedure and evidence, and this particular legacy is part of our national legal inheritance, or heritage. The challenge for each successive generation is to create a legacy that builds on prior generations' gains, and that future generations will feel inclined to embrace, rather than compelled to repudiate. 